\title{
Analisis Pengaruh Faktor Psikologis terhadap Keputusan Konsumen untuk Membeli Berita Tribun Manado di Kota Manado
}

\author{
Budi Nurgianto $^{1}$, Fredrik. G. Worang ${ }^{2}$, Bode Lumanauw ${ }^{2}$ \\ ${ }^{1}$ Mahasiswa Progam Studi Magister Manajemen Fakultas Ekonomi Dan Bisnis \\ Universitas Sam Ratulangi, Manado \\ ${ }^{2}$ Progam Studi Magister Manajemen Fakultas Ekonomi Dan Bisnis \\ Universitas Sam Ratulangi, Manado \\ ${ }^{1}$ Korespondensi email: b.nurgianto@gmail.com
}

Received: 04 Januari 2021; Revised: 26 Februari 2021; Accepted: 28 April 2021

DOI: http://dx.doi.org/10.37905/aksara.7.2.537-550.2021

\begin{abstract}
Abstrak
Jenis penelitian ini adalah penelitian yang dilakukan dengan menggunakan metode Regresi Linier Berganda untuk menjelaskan hubungan langsung dan tidak langsung serta faktor psikologis secara simultan dan parsial dari variabel Motivasi, Persepsi, Pembelajaran, Keyakinan, dan Sikap Terhadap Keputusan Konsumen untuk membeli Tribun Manado. koran di Kota Manado, Sulawesi Utara. Objek penelitian yang dipilih adalah Koran Harian Tribun Manado dengan jumlah sampel 120 responden. Teknik analisis data dengan bantuan software SPSS v.22.0 untuk Windows. Hasil penelitian menunjukkan bahwa motivasi (X1) berpengaruh terhadap Keputusan Pembelian (Y). Persepsi (X2) berpengaruh signifikan terhadap Keputusan Pembelian (Y), Pembelajaran (X3) berpengaruh signifikan terhadap Keputusan Pembelian (Y), Keyakinan (X4) tidak berpengaruh signifikan terhadap Keputusan Pembelian (Y)), dan Sikap (X5) berpengaruh positif dan signifikan terhadap Keputusan Pembelian (Y). Secara simultan semua variabel $\mathrm{X}$ berpengaruh signifikan terhadap Keputusan Pembelian (Y).
\end{abstract}

Kata Kunci: Motivasi, Persepsi, Pembelajaran, Keyakinan, Sikap dan Keputusan Pembelian

\begin{abstract}
This type of research is a research conducted using the Multiple Linear Regression method to explain the direct and indirect relationships as well as psychological factors simultaneously and partially from the variables of Motivation, Perception, Learning, Beliefs, and Attitudes Toward Consumer Decisions to Buy the Manado Tribune. newspaper in the city of Manado, North Sulawesi. The research object chosen was the daily newspaper Tribun Manado with a sample size of 120 respondents. Data analysis techniques with the help of SPSS v.22.0 for Windows software. The results showed that motivation (X1) had a significant effect on purchasing decisions (Y). Perception (X2) has a significant effect on Purchasing Decisions (Y), Learning (X3) has a significant effect on Purchasing Decisions (Y), Beliefs (X4) has no significant effect on Purchasing Decisions (Y)), and Attitudes (X5)) has a positive effect and significant to the Purchase Decision (Y).
\end{abstract}


Simultaneously all X variables have a significant effect on Purchasing Decision (Y).

Keywords: Motivation, Perception, Learning, Beliefs, Attitudes and Purchasing Decisions

\section{PENDAHULUAN}

Salah satu faktor stabilnya jumlah industri media di Kota Manado adalah perkembangan Kota Manado sebagai salah satu kota jasa dan bisnis di Kawasan Timur Indonesia. Perkembangan ini membuat banyak media cetak bertahan di tengah gencarnya kemajuan teknologi dan informasi. Pendapat masyarakat bahwa media cetak memiliki kepercayaan yang tinggi dalam penyampaian informasi membuatnya bertahan dan eksis di daerah. Pola pikir masyarakat lokal yang masih menggunakan media cetak sebagai rujukan informasi yang andal juga membuat para pengusaha mempertahankan bisnis medianya. Keputusan pembelian konsumen adalah langkah demi langkah yang digunakan konsumen saat membeli barang atau jasa atau keputusan karena adanya ketertarikan yang dirasakan seseorang terhadap suatu produk dan ingin membeli, mencoba, menggunakan, atau memiliki produk tersebut. Konsumen seringkali memiliki lebih dari dua pihak yang terlibat dalam proses pertukaran atau pembelian dalam pengambilan keputusan untuk membeli barang. (Koesoemaningsih, 2013). Schiffman dan Kanuk (2004: 547) mengatakan bahwa keputusan pembelian adalah memilih dua atau lebih alternatif pilihan keputusan pembelian, artinya seseorang dapat mengambil keputusan, harus ada beberapa alternatif pilihan yang tersedia. Keputusan untuk membeli dapat mengarah pada bagaimana proses pengambilan keputusan tersebut dilakukan. Menurut Kotler (2000: 201), keputusan pembelian merupakan proses pengambilan keputusan yang dilakukan oleh konsumen sebelum membeli suatu produk atau jasa.

Motivasi diartikan sebagai kemauan untuk melakukan upaya yang tinggi menuju tujuan yang ingin dicapai, dikondisikan oleh upaya untuk memenuhi kebutuhan individu. (Supriyanti, 2012). Motivasi merupakan proses dorongan agar konsumen termotivasi untuk membeli suatu produk. Motivasi terbentuk karena adanya rangsangan atau rangsangan yang akan menimbulkan kebutuhan akan pengenalan. Pengakuan kebutuhan akan menimbulkan tekanan pada konsumen sehingga ada dorongan pada mereka. Persepsi menurut Adhi, Shanti, \& NP (2016) menyatakan bahwa pengolahan informasi memiliki empat langkah utama, yaitu keterbukaan atau "eksposur", perhatian, interpretasi, dan memori. Tiga urutan pertama membentuk persepsi, yaitu: keterbukaan (eksposur), yang terjadi ketika rangsangan (stimulus) masuk dalam jangkauan reseptor sensorik kita. Gambaran dalam benak konsumen muncul karena proses persepsi; Bagaimana konsumen menilai kualitas layanan juga sangat ditentukan oleh persepsi. Konsumen baik secara langsung maupun tidak langsung akan memberikan penilaian terhadap layanan yang akan dibeli. Evaluasi dilakukan berdasarkan penilaian yang diterima dan dialami secara keseluruhan dibandingkan dengan yang diharapkan. Belajar adalah proses di mana individu memperoleh pengetahuan dan pengalaman tentang membeli dan mengonsumsi dengan menerapkannya pada perilaku masa depan. Belajar mendorong perubahan dalam perilaku kita yang muncul dari pengalaman. 
Dorongan adalah stimulus internal yang kuat yang mendorong tindakan jika pertanda adalah stimulus yang menentukan kapan, di mana, bagaimana seseorang merespons. (Schiffman dan Kanuk, 2007). Keyakinan adalah pemikiran deskriptif bahwa seseorang mempercayai sesuatu. Keyakinan dapat didasarkan pada pengetahuan, opini, dan keyakinan asli (Kotler dan Amstrong, 2006). Selain itu, sikap adalah kecenderungan yang dipelajari untuk berperilaku menyenangkan atau tidak menyenangkan terhadap objek tertentu. Berdasarkan latar belakang yang telah diuraikan diatas, maka peneliti tertarik untuk melakukan penelitian dengan judul "Analisis Pengaruh Faktor Psikologis Terhadap Keputusan Konsumen untuk Membeli Surat Kabar Tribun Manado di Kota Manado".

\section{METODE PENELITIAN}

Penelitian ini menggunakan metode penelitian kuantitatif yang menekankan pada analisis data numerik (bilangan) yang diolah dengan metode statistik. Penelitian kuantitatif bekerja dengan angka, yang datanya berupa angka (skor atau nilai, perangkat, atau frekuensi), yang dianalisis menggunakan statistik untuk menjawab pertanyaan atau hipotesis penelitian tertentu dan memprediksi variabel lain. Dengan kata lain penelitian ini merupakan penelitian asosiatif yang bertujuan untuk mengetahui pengaruh atau hubungan antara dua variabel atau lebih. Penelitian ini dapat membangun teori yang dapat berfungsi untuk menjelaskan, memprediksi dan mengendalikan suatu gejala dan dapat dilakukan untuk menguji hipotesis dengan statistik inferensial (korelasi, regresi,

2.1 Teknik Pengumpulan Data

Ada dua metode pengumpulan data yang dilakukan dalam penelitian ini dimana semua data yang dibutuhkan dikumpulkan

a. Penelitian lapangan (field research method) yaitu dengan menyebarkan kuesioner kepada seluruh responden yang menjadi objek penelitian.

b. Pengumpulan data juga dilakukan dengan metode studi pustaka, yaitu pengumpulan data dengan melakukan studi studi terhadap buku, literatur, catatan, dan laporan yang ada kaitannya dengan masalah yang sedang dipecahkan.

Penentuan jumlah sampel menurut Roscoe (metode penelitian untuk bisnis) di Albert tentang penentuan ukuran sampel untuk penelitian adalah "Jika penelitian akan menggunakan alat analisis multivariat, maka jumlah anggota sampel minimal sepuluh kali lipat jumlah variabel diteliti. Misal ada variabel penelitian (4 independen +1 dependen), maka jumlah sampel anggota $=10 \times 5=50 "$.

Penelitian ini menggunakan enam variabel ( 5 independen +1 dependen), dengan $20 \%$ subjek diambil berdasarkan penentuan sampel. Dengan demikian jumlah sampel anggota penelitian ini adalah $=20 \times 6=120$. Dari perhitungan tersebut maka jumlah sampel yang akan diteliti adalah 120 responden. 


\section{HASIL DAN PEMBAHASAN \\ Uji validitas}

Uji validitas digunakan untuk mengukur valid tidaknya suatu kuesioner. Suatu kuesioner valid jika pertanyaan kuesioner dapat mengungkapkan sesuatu yang akan diukur kuesioner tersebut. Uji validitas dihitung dengan membandingkan nilai $r$ hitung (korelasi item-total korelasi) dengan nilai $r$ tabel. Jika $r$ hitung $>r$ tabel dan nilainya positif, maka item atau pertanyaan tersebut dinyatakan valid (Ghozali, 2005: 45).Dalam penelitian ini uji validitas dilakukan dengan menggunakan program SPSS 22.

\section{Tes kepercayaan}

Reliabilitas adalah sejauh mana hasil pengukuran dapat dipercaya. Uji reliabilitas adalah data untuk mengukur suatu kuesioner yang berupa indikator variabel atau konstruk. Kuesioner dapat diandalkan atau dapat diandalkan jika jawaban seseorang atas suatu pernyataan konsisten atau stabil dari waktu ke waktu. Reliabilitas menyangkut konsistensi jawaban jika diuji berulang kali pada sampel yang berbeda. SPSS menyediakan fasilitas untuk mengukur reliabilitas dengan uji statistik Cronbach Alpha $(\alpha)$. Variabel konstruktor reliabel jika memberikan nilai Cronbach Alpha> 0,60 (Ghozali, 2005: 41-42). Reliabilitas dalam penelitian ini dilakukan dengan mengukur korelasi antara jawaban soal menggunakan SPSS 22, dengan uji statistik Cronbach alpha $(\alpha)$.

\section{Analisis Regresi Linear Berganda}

Teknik analisis data adalah teknik analisis regresi linier berganda. Metode ini digunakan karena dapat menguji hipotesis satu sampai sembilan variabel.Dalam analisis ini dapat dilihat bagaimana variabel independen yaitu Motivasi (X1), Persepsi (X2), Pembelajaran (X3), Keyakinan (X4), dan Sikap (X5) mempengaruhi (secara positif maupun negatif) variabel dependen yaitu Keputusan Pembelian Surat Kabar Tribun Manado. (Y). Selain itu, bentuk matematika umumnya adalah sebagai berikut:

$$
\mathrm{Y}=\mathrm{a}+\mathrm{b} 1 \mathrm{X} 1+\mathrm{b} 2 \mathrm{X} 2+\mathrm{b} 3 \mathrm{X} 3+\mathrm{b} 4 \mathrm{X} 4+\mathrm{b} 5 \mathrm{X}+\mathrm{e}
$$

Dimana:

$$
\begin{aligned}
& \mathrm{Y}=\text { Keputusan Pembelian } \\
& \mathrm{a}=\text { Konstanta persamaan regresi } \\
& \text { b1 }=\text { koefisien regresi variabel X1 (motivasi) } \\
& \text { b2 }=\text { koefisien regresi variabel X2 (persepsi) } \\
& \text { b3 }=\text { koefisien regresi variabel X3 (pembelajaran) } \\
& \text { b4 }=\text { koefisien regresi variabel X4 (kepercayaan) } \\
& \text { b5 }=\text { koefisien regresi variabel X5 (sikap) } \\
& \text { X1 }=\text { Motivasi } \\
& \text { X2 }=\text { Persepsi } \\
& \text { X3 }=\text { Belajar } \\
& \text { X4 }=\text { Keyakinan } \\
& \text { X5 }=\text { Sikap } \\
& \text { e }=\text { Variabel perancu }
\end{aligned}
$$

Pengujian hipotesis pertama sampai keenam dengan menentukan tingkat signifikansi dengan uji simultan (uji F dan R2) dan uji parsial (uji t) sebagai berikut: 


\section{Uji Determinasi (R2)}

Uji determinasi digunakan untuk mengukur sejauh mana kemampuan model dalam menjelaskan variasi variabel dependen. Koefisien determinasi berada di antara nol dan satu. Nilai yang mendekati satu berarti variabel independen menyediakan hampir semua informasi yang dibutuhkan untuk memprediksi variasi variabel dependen.

\section{Uji F}

Uji F untuk menguji pengaruh secara simultan variabel motivasi, persepsi, pembelajaran, keyakinan, dan sikap terhadap keputusan konsumen membeli koran Manado Tribune. Pedoman yang digunakan untuk menerima atau menolak hipotesis adalah:

- Ha diterima jika F-hitung> F-tabel atau nilai-p pada kolom sig. $<$ tingkat signifikan $(\alpha) 5 \%$ artinya semua variabel independen secara bersama-sama mempengaruhi variabel dependen.

- H0 diterima jika F-hitung <F-tabel atau p-value pada kolom sig.> Tingkat signifikansi $(\alpha) 5 \%$ artinya semua variabel independen tidak berpengaruh secara bersama-sama terhadap variabel dependen.

\section{Tes uji-t}

Uji $\mathrm{t}$ t digunakan untuk menguji pengaruh parsial variabel motivasi, persepsi, pembelajaran, keyakinan, dan sikap terhadap keputusan konsumen membeli koran Manado Tribune. Pedoman yang digunakan untuk menerima atau menolak hipotesis adalah:

1. Ha diterima jika t-hitung $>\mathrm{t}$-tabel atau nilai prob-nilai pada kolom sig. <level of signifikan $(\alpha) 5 \%$ artinya variabel independen berpengaruh terhadap variabel dependen.

2. H0 diterima jika t-hitung <t-tabel atau nilai prob-value pada kolom sig $>$ taraf signifikan $(\alpha) 5 \%$ artinya variabel independen tidak berpengaruh terhadap variabel dependen.

Tabel 1. Hasil uji validitas instrumen penelitian

\begin{tabular}{|c|c|c|c|c|}
\hline $\begin{array}{c}\text { Tida } \\
\text { k. }\end{array}$ & Variabel & $\begin{array}{c}\text { Baran } \\
\mathbf{g}\end{array}$ & korelasi $\mathbf{r}$ & Informasi \\
\hline 1 & \multirow[t]{6}{*}{ Motivasi (X1) } & $\mathrm{X} 1.1$ & 0,695 & Sah \\
\hline 2 & & $\mathrm{X} 1.2$ & 0,698 & Sah \\
\hline 3 & & $\mathrm{X} 1.3$ & 0.895 & Sah \\
\hline 4 & & $\mathrm{X} 1.4$ & 0.763 & Sah \\
\hline 5 & & $\mathrm{X} 1.5$ & 0.774 & Sah \\
\hline 6 & & $\mathrm{X} 1.6$ & 0.705 & Sah \\
\hline 7 & \multirow[t]{4}{*}{ Persepsi (X2) } & $\mathrm{X} 2.1$ & 0.701 & Sah \\
\hline 8 & & $\mathrm{X} 2.2$ & 0848 & Sah \\
\hline 9 & & $\mathrm{X} 2.3$ & 0,906 & Sah \\
\hline 10 & & $\mathrm{X} 2.4$ & 0.792 & Sah \\
\hline
\end{tabular}




\begin{tabular}{|c|c|c|c|c|}
\hline 11 & & $\mathrm{X} 2.5$ & 0852 & Sah \\
\hline 12 & \multirow[t]{5}{*}{ Belajar (X3) } & $\mathrm{X} 3.1$ & 0844 & Sah \\
\hline 13 & & $\mathrm{X} 3.2$ & 0.789 & Sah \\
\hline 14 & & X3.3 & 0.794 & Sah \\
\hline 15 & & X3.4 & 0,522 & Sah \\
\hline 16 & & $\mathrm{X} 3.5$ & 0.445 & Sah \\
\hline 17 & \multirow[t]{6}{*}{ Keyakinan (X4) } & $\mathrm{X} 4.1$ & 0.769 & Sah \\
\hline 18 & & $\mathrm{X} 4.2$ & 0847 & Sah \\
\hline 19 & & $\mathrm{X} 4.3$ & 0.898 & Sah \\
\hline 20 & & $\mathrm{X} 4.4$ & 0,918 & Sah \\
\hline 21 & & $\mathrm{X} 4.5$ & 0,936 & Sah \\
\hline 22 & & $\mathrm{X} 4.6$ & 0,900 & Sah \\
\hline 23 & \multirow[t]{6}{*}{ Sikap (X5) } & $\mathrm{X} 5.1$ & 0,628 & Sah \\
\hline 24 & & $\mathrm{X} 5.2$ & 0.771 & Sah \\
\hline 25 & & $\mathrm{X} 5.3$ & 0.797 & Sah \\
\hline 26 & & $\mathrm{X} 5.4$ & 0.777 & Sah \\
\hline 27 & & $\mathrm{X} 5.5$ & 0,565 & Sah \\
\hline 28 & & $\mathrm{X} 5.6$ & 0.727 & Sah \\
\hline 29 & \multirow[t]{6}{*}{ Keputusan Pembelian (Y) } & Y1.1 & 0,560 & Sah \\
\hline 30 & & Y1.2 & 0,538 & Sah \\
\hline 31 & & Y1.3 & 0.632 & Sah \\
\hline 32 & & Y1.4 & 0,594 & Sah \\
\hline 33 & & Y1.5 & 0.663 & Sah \\
\hline 34 & & Y1.6 & 0.603 & Sah \\
\hline
\end{tabular}

Sumber: Data Primer (diolah), April 2020

Dari hasil uji validitas instrumen di atas diketahui bahwa semua item variabel dalam penelitian ini dinyatakan valid dan dapat dimasukkan dalam analisis lebih lanjut. Nilai instrumen dalam penelitian ini memiliki nilai korelasi antara skor item dengan skor total lebih dari 0,176 .

\section{B. Uji Reliabilitas}

Uji reliabilitas digunakan untuk mengetahui apakah alat pengumpul data menunjukkan akurasi, tingkat akurasi, stabilitas, atau konsistensi dalam mengungkapkan gejala tertentu (Sugiyono 2010: 178).

Uji reliabilitas yang digunakan peneliti adalah untuk menilai konsistensi objek dan data, apakah instrumen yang digunakan beberapa kali untuk mengukur objek yang sama akan menghasilkan data yang sama. Koefisien Cronbach Alpha digunakan sebagai derajat konsistensi data. Kriteria keputusan uji reliabilitas adalah sebagai berikut: 
- Jika koefisien Cronbach Alpha> 0,60 - 0-80 dikatakan reliabel

- Jika koefisien Cronbach Alpha> 0,60 - 0-80, maka sangat reliabel

Dari hasil uji reliabilitas instrumen diketahui bahwa semua variabel memiliki nilai cronbach alpha diatas 0,6 sehingga butir instrumen dinyatakan reliabel untuk digunakan dalam analisis selanjutnya. Hasil reliabilitas dalam penelitian ini disajikan pada Tabel 5.3 di bawah ini

Tabel 2. Hasil Uji Reliabilitas Instrumen Penelitian

\begin{tabular}{|c|l|c|c|}
\hline $\begin{array}{c}\text { Tid } \\
\text { ak. }\end{array}$ & \multicolumn{1}{|c|}{ Variabel } & Alpha Cronbach & Informasi \\
\hline 1 & Motivasi (X1) & 0849 & Andal \\
\hline 2 & Persepsi (X2) & 0.878 & Andal \\
\hline 3 & Belajar (X3) & 0.726 & Andal \\
\hline 4 & Keyakinan (X4) & 0,941 & Andal \\
\hline 5 & Sikap (X5) & 0811 & Andal \\
\hline 6 & Keputusan Pembelian (Y) & 0.711 & Andal \\
\hline
\end{tabular}

Sumber: data primer (diolah), April 2020

Dari hasil uji reliabilitas instrumen penelitian di atas diketahui bahwa semua item variabel dalam penelitian ini dinyatakan reliabel dan dapat dimasukkan dalam analisis lebih lanjut.

\title{
4. Uji hipotesis
}

Hasil penelitian ini dilakukan dengan menggunakan analisis regresi linier berganda dan analisis perhitungan menggunakan SPSS 22.0.

\section{A. Uji Regresi Linier Berganda}

Dari hasil analisis regresi linier berganda dengan menggunakan SPSS 22.0, maka hipotesis penelitian akan dibuktikan sebagaimana dijelaskan pada Bab IV. Hasil rekap analisis regresi linier berganda adalah sebagai berikut:

\section{Uji Determinan}

Tabel 4. Hasil Uji Determinan

\begin{tabular}{|c|c|c|c|c|}
\hline Model & R & R Square & $\begin{array}{c}\text { R Square yang } \\
\text { disesuaikan }\end{array}$ & $\begin{array}{c}\text { Std Error dari } \\
\text { estimasi }\end{array}$ \\
\hline 1 & $0,778 \mathrm{a}$ & .605 & 0,593 & 0,26946 \\
\hline
\end{tabular}

\section{Keyakinan}

Nilai R Square yang disajikan pada tabel 5.5 di atas menunjukkan nilai 0,605 atau $60,50 \%$. Dapat diartikan bahwa $(60,50 \%)$ keputusan konsumen untuk membeli produk koran Tribun Manado dipengaruhi oleh variabel-variabel seperti motivasi, persepsi, pembelajaran, keyakinan, dan sikap. Sebagai perbandingan, 39,50\% sisanya dijelaskan oleh variabel lain di luar variabel motivasi - persepsi, pembelajaran, keyakinan, dan sikap. Nilai R Square dalam penelitian ini tergolong tinggi, sehingga dapat dikatakan motivasi, persepsi, pembelajaran, keyakinan, dan sikap berpengaruh kuat terhadap keputusan konsumen untuk membeli produk dari koran Tribun Manado. 


\section{B. Tes uji-t}

Uji t t digunakan untuk menguji pengaruh parsial variabel motivasi, persepsi, pembelajaran, keyakinan, dan sikap terhadap keputusan konsumen membeli koran Manado Tribune. Pedoman atau dasar pengambilan keputusan yang digunakan untuk menerima atau menolak hipotesis penelitian ini, yaitu:

- Ha diterima jika t-hitung> t-tabel atau nilai prob-nilai pada kolom sig. <level of signifikan $(\alpha) 5 \%$ artinya variabel independen berpengaruh terhadap variabel dependen.

- H0 diterima jika t-hitung <t-tabel atau nilai prob-value pada kolom sig> taraf signifikan $(\alpha) 5 \%$ artinya variabel independen tidak berpengaruh terhadap variabel

Tabel 5. Hasil Koefisien

\begin{tabular}{|l|c|c|c|c|c|}
\hline \multirow{2}{*}{ Model } & \multicolumn{2}{|c|}{$\begin{array}{c}\text { Koefisien Tidak } \\
\text { Standar }\end{array}$} & \multirow{2}{*}{ Koefisien Standar } & \multirow{2}{*}{} \\
\cline { 2 - 4 } & $\mathrm{B}$ & $\begin{array}{c}\text { Std. } \\
\text { Kesalahan }\end{array}$ & Beta & $\mathrm{t}$ & Sig. \\
\hline (Konstan) & 8.586 & 2.195 & & 3.911 & .000 \\
Motivasi & 0,340 & 0,074 & 0,355 & 4.544 & .000 \\
\hline Persepsi & 0,348 & 0,082 & 0,315 & 4.237 & .000 \\
Belajar & 0,372 & 0,072 & 0,376 & 4.974 & .000 \\
Kepercayaan & 0,026 & 0,064 & 0,044 & 0,402 & 0,689 \\
Sikap & 0,465 & 0,089 & 0,461 & 5.213 & .000 \\
\hline
\end{tabular}

dependen.

Sebuah. Variabel Dependen: Keputusan Pembelian

Berdasarkan hasil pengujian nilai t-hitung pada penelitian ini didapatkan nilai T-tabel untuk jumlah observasi adalah 120 dengan taraf alpha (5\%). dan $\mathrm{k}$ atau banyaknya semua variabel baik variabel independen maupun variabel dependen adalah 6, maka nilai T-tabelnya adalah $\mathrm{T}$-tabel $=\mathrm{t}(\mathrm{a} / 2$; nk-1) $=\mathrm{T}$-tabel $(0,025$; $114)=1,980$. Dari hasil perhitungan tersebut, dapat dibuat detail sebagai berikut:

1. Pengaruh motivasi (X1) terhadap keputusan konsumen membeli koran Manado Tribune di Kota Manado.

Dari hasil perhitungan menggunakan SPSS 22.0 didapatkan t-hitung 4,544 dengan probabilitas (p-value) sebesar 0,000. Berikutpedoman atau dasar pengambilan keputusan yang digunakan untuk menerima atau menolak hipotesis, diketahui nilai T-hitung lebih besar dari T-tabel atau 4,544 <1,980 atau n. Nilai probabilitas lebih signifikan dari alpha (5\%) atau 0,000>0,05. Dengan demikian, dapat disimpulkan bahwa motivasi berpengaruh signifikan terhadap keputusan konsumen untuk membeli produk dari koran Manado Tribune. Hipotesis yang menyatakan bahwa "motivasi berpengaruh signifikan terhadap keputusan konsumen membeli koran Tribun Manado di Kota Manado" terbukti signifikan.

2. Pengaruh Persepsi (X2) terhadap Keputusan Konsumen untuk Membeli Koran Manado Tribune di Kota Manado

Dari hasil perhitungan menggunakan SPSS 22.0 didapatkan t-hitung sebesar 4,237 dengan probabilitas ( $\mathrm{p}$-value) sebesar 0,000. Berikutpedoman atau dasar 
pengambilan keputusan yang digunakan untuk menerima atau menolak hipotesis, nilai T-hitung lebih besar dari pada T-tabel atau4.237<1.980 atau n. Nilai probabilitas ini lebih kecil dari alpha $(5 \%)$ atau $0,000>0,05$.

Dengan demikian, dapat disimpulkan bahwa persepsi berpengaruh signifikan terhadap keputusan konsumen untuk membeli produk dari koran Manado Tribune. Artinya, hipotesis penelitian yang menyatakan bahwa ada pengaruh persepsi terhadap keputusan konsumen membeli produk koran Manado Tribune adalah signifikan.

3. Pengaruh pembelajaran (X3) terhadap keputusan konsumen membeli koran Manado Tribune di Kota Manado

Dari hasil perhitungan menggunakan SPSS 22.0 didapatkan t-hitung sebesar 4,974 dengan probabilitas (p-value) sebesar 0,000. Berikutpedoman atau dasar pengambilan keputusan yang digunakan untuk menerima atau menolak hipotesis, nilai T-hitung lebih besar dari pada T-tabel atau4.974 <1.980 atau n. Nilai probabilitas ini lebih kecil dari alpha (5\%) atau 0,000>0,05. Dengan demikian, dapat disimpulkan bahwa pembelajaran berpengaruh signifikan terhadap keputusan konsumen untuk membeli produk surat kabar Manado Tribune. Artinya, hipotesis penelitian yang menyatakan bahwa ada pengaruh pembelajaran terhadap keputusan konsumen membeli produk koran Manado Tribune terbukti signifikan.

\section{Diskusi}

\section{Motivasi Keputusan Pembelian}

Hasil analisis data dalam penelitian ini menunjukkan bahwa motivasi berpengaruh signifikan terhadap keputusan masyarakat Kota Manado dalam membeli produk dari koran Tribun Manado. Dari tabel analisis uji-t Koefisien diketahui bahwa secara parsial motivasi konsumen berpengaruh signifikan terhadap keputusan pembelian produk surat kabar Tribun Manado. Sedangkan hasil koefisien regresi diperoleh nilai positif atau mempunyai pengaruh searah, artinya semakin tinggi motivasi maka semakin tinggi pula masyarakat Kota Manado untuk memutuskan membeli produk koran Tribun Manado. Hasil penelitian ini sejalan dengan hasil penelitian Rico Saputra (2013), Hizkia Elfran Mawe (2013), Vernando Satria Wijaya (2014), Sisilya Truly Reto (2014) yang menegaskan bahwa motivasi berpengaruh signifikan. tentang keputusan pembelian. Merna Tompunu (2014) bahkan menyatakan bahwa motivasi baik secara parsial maupun simultan sangat berpengaruh terhadap keputusan pembelian konsumen. Hal ini menunjukkan bahwa masyarakat Kota Manado yang menjadi responden penelitian mempertimbangkan motivasi untuk menentukan keputusan pembelian koran Tribun Manado. Pembelian produk berdasarkan motivasi yang lebih kuat oleh konsumen dianggap dapat mengarah pada keputusan pembelian yang lebih signifikan. Dapat dikatakan bahwa motivasi merupakan salah satu elemen atau variabel yang dapat mempengaruhi konsumen untuk membeli produk koran Tribun Manado. Pendapat bahwa surat kabar diperlukan membuat masyarakat Kota Manado memiliki motivasi dan stimulasi tersendiri dalam mengambil keputusan pembelian. Motivasi berasal dari dalam atau luar (lingkungan) yang menjadi faktor pendorong tercapainya tujuan. Bagi konsumen, motivasi dapat diartikan sebagai dorongan yang menggerakkan konsumen untuk memutuskan mencapai tujuan, yaitu memenuhi berbagai macam kebutuhan dan keinginan. Dalam artian 
kebutuhan membangkitkan motivasi, dan pada akhirnya akan memunculkan mekanisme perilaku, yang menurut Merle J. Moscowitz, sebagai inisiasi dan arah pelajaran perilaku dan motivasi adalah pelajaran tentang perilaku.

\section{Persepsi Keputusan Pembelian}

Hasil analisis data dalam penelitian ini menunjukkan bahwa persepsi berpengaruh signifikan terhadap keputusan masyarakat Kota Manado untuk membeli produk surat kabar Tribun Manado. Analisis uji t tabel diketahui; secara parsial persepsi berpengaruh signifikan terhadap keputusan pembelian surat kabar Manado Tribune. Sedangkan hasil koefisien regresi diperoleh nilai positif atau mempunyai pengaruh searah, artinya semakin tinggi persepsi masyarakat Kota Manado terhadap produk koran Tribun Manado maka semakin tinggi pula masyarakat Kota Manado. Mereka memutuskan untuk membeli produk koran. Hasil penelitian ini sejalan dengan hasil penelitian yang dilakukan oleh Senjaya, Fredy (2011), Mashadi (2012), Machrani Rinandha Bilondatu (2013), Siti Kumala Dewi, dan Herning Indriastuti (2017) yang menunjukkan bahwa persepsi memiliki berpengaruh signifikan terhadap keputusan pembelian konsumen. Persepsi bahkan memiliki pengaruh yang cukup signifikan dalam mendorong konsumen untuk memutuskan membeli suatu produk. Persepsi konsumen terhadap suatu produk menjadi pertimbangan dalam menentukan pilihan produk yang akan dibeli. Bisa disebut proses pengorganisasian, menafsirkan rangsangan yang diterima oleh suatu organisme atau individu menjadi sesuatu yang bermakna, dan merupakan kegiatan yang terintegrasi dalam diri individu tersebut. Kotler dan Armstrong (1996) mengemukakan bahwa persepsi seseorang terhadap suatu produk dapat disebabkan oleh proses seleksi untuk berbagai rangsangan yang ada dalam situasi yang sama. Dapat dikatakan bahwa persepsi berkaitan dengan perilaku konsumen dalam mengambil keputusan tentang apa yang diinginkan.

\section{Belajar Melawan Keputusan Pembelian}

Dari hasil perhitungan diketahui nilai t untuk variabel pembelajaran dalam penelitian ini adalah 4,974 dengan probabilitas (p-value) sebesar 0,000. bahwa pembelajaran berpengaruh signifikan terhadap keputusan konsumen membeli produk koran Tribun Manado. Dengan kata lain, pembelajaran bahkan menjadi salah satu variabel yang mempengaruhi masyarakat Kota Manado dalam membeli produk dari koran Tribun Manado. Hasil penelitian ini sejalan dengan penelitian yang dilakukan oleh Rico Saputra (2013), Steffi Gunawan (2015), dan Ch. Endah Winarti (2015) mengungkapkan bahwa pembelajaran berpengaruh signifikan terhadap keputusan pembelian konsumen. Julia, Vivin Fauzana (2019) bahkan mengkonfirmasi bahwa secara simultan atau parsial variabel pembelajaran mempengaruhi keputusan pembelian. Wahyuni (2008) bahkan mengungkapkan bahwa pembelajaran konsumen dapat menjadi alasan mendasar untuk membeli dan produk mana yang akan dipertimbangkan oleh pelanggan, yang akan mempengaruhi pelanggan dalam memutuskan produk mana yang akan dibeli. Pembelajaran produk secara terus menerus akan mendorong psikologi konsumen untuk melakukan pembelian. Pembelajaran yang tinggi membuat konsumen lebih bertekad untuk melakukan pembelian, begitu pula sebaliknya; Jika proses pembelajaran rendah, maka kemungkinan konsumen untuk membeli suatu produk akan berkurang. 


\section{PENUTUP}

Dari hasil penelitian dan pembahasan pada bab sebelumnya dapat disimpulkan sebagai berikut:

1. Motivasi yang terdiri dari harga dan kualitas secara bersama-sama berpengaruh signifikan terhadap keputusan konsumen membeli koran Tribun Manado di Kota Manado. Hipotesis penelitian yang menyatakan bahwa "motivasi berpengaruh signifikan terhadap keputusan konsumen membeli koran Tribun Manado di Kota Manado" terbukti signifikan.

2. Hasil analisis data diketahui nilai $t$ variabel persepsi dalam penelitian ini adalah 4,237 dengan probabilitas (p-value) sebesar 0,000. Dengan demikian secara parsial persepsi berpengaruh signifikan terhadap keputusan konsumen membeli produk koran Tribun Manado. Hipotesis penelitian yang menyatakan bahwa ada pengaruh persepsi terhadap keputusan konsumen membeli produk surat kabar Tribun Manado adalah signifikan.

3. Berdasarkan hasil penelitian diketahui secara parsial nilai t hitung variabel pembelajaran dalam penelitian ini adalah 4,974 dengan probabilitas ( $\mathrm{p}$ value) sebesar 0,000. Dengan demikian, variabel pembelajaran penelitian ini berpengaruh signifikan terhadap keputusan konsumen membeli produk surat kabar Manado Tribune. Hipotesis penelitian menyatakan bahwa "terdapat pengaruh pembelajaran terhadap keputusan konsumen membeli produk koran Tribun Manado" terbukti signifikan.

\section{DAFTAR PUSTAKA}

Assael.H. (2001). Perilaku konsumen. Edisi keenam. New York: Pembelajaran Thomson.

Azuwar dkk. (2013), Pengaruh Motivasi, Sikap Dan Bauran Pemasaran Terhadap Perilaku Konsumen Pembelian Air Mineral Merek Seria Di Wilayah Sungai Penuh, Jurnal Manajemen Vol.1 No.1 Desember

Dewi.UW (2008), Pengaruh Motivasi, Persepsi, dan Sikap Konsumen Terhadap Keputusan Pembelian Sepeda Motor "Honda" di Surabaya Barat. Jurnal Manajemen dan Kewirausahaan, Vol. 10, No. 1 Maret

Endah.CH. (2015),Pengaruh Motivasi Konsumen, Persepsi Kualitas, Sikap Konsumen, dan Harga terhadap Keputusan Pembelian Mobil Nissan Grand Livina di Central Dealer PT Nissan Motor Indonesia Jln. MT Haryono Kav. 10 Jakarta Timur, Jurnal Manajemen dan Bisnis, Vol. 3 No.1, Juli

Elfran.H. (2013), Motivasi, Persepsi, dan Sikap Konsumen Dampak Terhadap Keputusan Pembelian Produk PT. Rajawali Nusindo, Cabang Manado, Jurnal EMBA 791 Vol.1 No.4 Desember

Fadila.D dan Zainal.R. (2013). Perilaku konsumen. Citra Books Indonesia: Palembang

Fajaruddin.A. (2012) Analisis Pengaruh Motivasi, Persepsi, dan Sikap Konsumen terhadap Keputusan Pembelian, Jurnal BISNUS Vol.01. Tidak. 3 Agustus

Fauzi.A. (2018), Pengaruh Inovasi Produk, Sikap Konsumen dan Iklan Terhadap Keputusan Pembelian Sepeda Motor Yamaha Di CV Sejati Mitra Motor Medan Maryland, International Journal Of Scientific \& Technology Research Volume 7, Issue 12, December 
Ferdinand.AT (2006). Manajemen Pemasaran: Pendekatan Strategis. Badan Penerbitan Universitas Diponegoro

Gunawan.S. (2015), The Impact of Motivation, Perception, and Attitude to Consumer Purchasing Decision: A Study Case of Surabaya and Jakarta Society on Carl's Junior, iBUSS Menegement Vol.03, No, 2, March 2015

Ghozali, Imam, (2005), Aplikasi Analisis Multivariate dengan Program SPSS, Badan Penerbit Universitas Diponegoro, Semarang

Ghozali, Imam, (2005), Aplikasi dengan Program AMOS 16.0, Badan Penerbitan Universitas Diponegoro, Semarang

Maleke. CL, (2013). Pengaruh Faktor Sosial, Pribadi, dan Psikologis terhadap Keputusan Pembelian Blackberry Gemini pada PT. Megamitra Makmur Sejahtera, Jurnal EMBA 551 Vol.1 No.3 September 2013

Manan.A. (2018). Ancaman Baru Dari Digital. Jakarta. Aliansi Jurnalis Independen Indonesia

Mashadi. (2012), Pengaruh Motivasi, Persepsi, Sikap dan Pembelajaran terhadap Keputusan Pembelian Minuman Teh Botol Sosro di Depok, Jurnal Manajemen Vol. 04, No. 02, November 2012

Mansour.HF, dan Abdelgardir MA (2016). Sikap Konsumen terhadap Layanan EBanking di Bank Islam: Kasus Sudan. Review Bisnis dan Strategi Internasional. Vol. 26 Iss 2 hlm.244-260.

Miftah.T. (2007), Kepemimpinan dalam Manajemen. Jakarta: PT. Raja. Grafilld

Mulyadi dan Rivai. (2009). Manajemen Sumber Daya Manusia, Jakarta dalam cetakan kesembilan

Nugroho.Y. (2012). Pemetaan Kebijakan Media di Indonesia, Pusat Kebijakan dan Tata Kelola Inovasi. 2012

Nazir.M. (2014). Metode penelitian. Jakarta: Ghalia Indonesia

Julia.VF (2019) Pengaruh Motivasi, Persepsi, Pembelajaran, dan Sikap Terhadap Keputusan Pembelian Konsumen Jasa Angkutan Lion Air di Kota Malang, Jurnal Ekonomi dan Bisnis, Vol. 6, No. 1, Juli 2019

Jogiyanto. (2007). Sistem Informasi Perilaku. Yogyakarta: Andi.

Kairupan. MC, (2013). Sikap, Keyakinan, dan Efektivitas Iklan Mempengaruhi Keputusan Penggunaan Produk US Card bagi Konsumen di Manado Town Square, Jurnal EMBA vol.1 No.3 September 2013.

Kumal.S. (2017). Pengaruh Motivasi, Persepsi dan Sikap Konsumen terhadap Keputusan Pembelian Mobil, Jurnal Manajemen Vol. 9. Februari 2017

Kotler, Plilip (2009). Manajemen Pemasaran. Volume I. Edisi 13. Jakarta: Erlangga Yudhi. (2008), "Pengaruh Kualitas Produk, Merek dan Desain terhadap Keputusan Pembelian Sepeda Motor Yamaha Mio," Jurnal EMBA. Vol. 1, No. 3, Juni 2008

Laksmi, SH (2007). Indonesia: Alternative Media Menikmati Angin Segar, dalam Seneviratne, K. (Ed.), Media Pluralism in Asia: The Role and Impact of Alternative Media. Jakarta. Pusat Media dan Informasi Asia

Lomboan.R. (2013). Pengaruh Motivasi dan Persepsi sebagai Faktor Psikologis Terhadap Keputusan Pembelian Sepeda Motor Kawasaki Ninja, Jurnal EMBA Vol.1 No.4 Desember 
Long-Yi. (2012). The Relationship of University Student's Lifestyle, Money Attitude, Personal Value, and Purchase Decision, International Journal of Research in Management, Issue2, Vol. 1. Januari 2012

Umar, H. (2003). Riset Pemasaran dan Perilaku Konsumen. PT. Gramedia Pustaka Utama, Jakarta

Rahma.D.(2015). Pengaruh Motivasi, Persepsi, Sikap Konsumen, Kualitas Layanan dan Promosi Terhadap Keputusan Pembelian Toyota Yaris Di Padang, Jurnal Ekonomi. Vol.6. No, 2. Maret 2015

Rakhmat.J. (2012). Psikologi Komunikasi. Bandung: PT Remaja Rosdakarya

Rudianto, Teguh. (2017). Pengaruh Motivasi, Persepsi dan Sikap Konsumen terhadap Keputusan Pembelian Material di Ud Teguh Kramik Jaya Jepara, Jurnal Ilmu Sosial dan Ekonomi. Vol. 4. No.2, September

Reagi.G, I. (2011), Analisis Pengaruh Motivasi Konsumen, Persepsi Konsumen, dan Sikap Konsumen Terhadap Keputusan Pembelian (Studi di Kecamatan di Semarang. Jurnal Ekonomi, Vol.8.No10, Oktober 2011)

Rinandha.M. (2013). Motivasi, Persepsi, dan Keyakinan Pengaruhnya terhadap Keputusan Pembelian Konsumen pada Sepeda Motor Yamaha di Minahasa, Jurnal EMBA Vol.1 No.3 September 2013

Suryani.T. (2013). Perilaku Konsumen di Era Internet. Yogyakarta: Penerbit Graha Ilmu

Saputra. R (2013), Analisis Pengaruh Motivasi, Persepsi, Sikap Konsumen terhadap Keputusan Pembelian Daihatsu Xenia di Sidoarjo. Jurnal Manajemen Pemasaran Vol.1, No.1, Februari

Satria.W dan Vernando. (2014), Pengaruh Motivasi, Persepsi, dan Sikap Konsumen terhadap Keputusan Pembelian Mobil Honda di Kabupaten Kudus, Jurnal Ekonomi dan Bisnis. Vol.9.No.3. Oktober

Setiawan, R., Pio, L., Cavaliere, L., Sankaran, D., Rani, K., Yapanto, LM, Laskar, NH, Raisal, I., Christabel, GJA, Setiawan, R ., Petra, Inggris, Airlangga, U., Pio, L., Cavaliere, L., \& Foggia, U. (nd). Akses ke Layanan Keuangan dan Pemberdayaan Perempuan melalui kelayakan Keuangan Mikro. 1, 841-859.

Setyo. (2012), Pengaruh Iklan Televisi dan Harga terhadap Keputusan Pembelian Sabun Lux, Jurnal Riset Sains Indonesia. Vol. 3, No. 1. April

Suryawardana. dkk (2019), Analisis Faktor-Faktor Yang Mempengaruhi Mahasiswa Dan Mahasiswa Terhadap Keputusan Membeli Produk Melalui Aplikasi Online Di Semarang, Jurnal Menegement Vo.8.No1. April

Schiffman dan Kanuk (2007). Perilaku konsumen. Edisi kedua. Jakarta: PT. Indeks Gramedia

Swastha. (2000), Pengantar Bisnis Modern, Pengantar Ekonomi Perusahaan Modern, Jakarta: Liberty

Tompunu, Merna (2014), Analisis Motivasi, Persepsi, Pembelajaran, dan Sikap Konsumen Dampaknya terhadap Keputusan Pembelian di KFC Bahu Mall Manado, Jurnal EMBA Vol.2 No. 3 September 2014, Hal. 610-621

Benar-benar Retor.S. (2014), Analisis Motivasi, Persepsi, Pembelajaran, Keyakinan dan Sikap terhadap Keputusan Pembelian pada PT. Conbloc Indonesia Surya Manado, Jurnal EMBA Vol.2 No.3 September 
Thogersen.J. (2013). Motif dan Sikap Membeli Konsumen Terhadap Makanan Organik di Dua Pasar Berkembang: Cina dan Brasil, Jurnal Pemasaran Internasional Edisi 3, Vol. 3

Sugiyono. (2006). Metode Penelitian Kualitatif dan Kuantitatif R \& D. Alfabet, Bandung

Wahyudhi. (2019). Pengaruh Sikap Perilaku Konsumen Terhadap Keputusan Pembelian Produk Indhihome Terkait Pelaksanaan Program CRS (Corporate Social Responsibility), Earth and Environmental Science Journal, Vol. 343

Yan Januar Akbar. (2010). Analisis Pengaruh Motivasi Konsumen, Persepsi Kualitas, dan Sikap Konsumen terhadap Keputusan Pembelian Sepeda Motor Honda di Semarang

Yuliawan, Eko, (2018). Analisis Pengaruh Faktor Kepercayaan, Kemudahan dan Kualitas Layanan terhadap Keputusan Pembelian di Toko Online Zalora Indonesia, (Studi pada Mahasiswa Prodi Manajemen STIE Mikroskil Medan), Jurnal OPTIMAL Vol.12 no.2, 2018 